\title{
VARIASI DAN REKONSTRUKSI FONOLOGIS ISOLEK KERINCI: STUDI DIALEKTOLOGI DIAKRONIS DI KECAMATAN BUKIT KERMAN
}

\author{
Rengki Afria \\ Program Studi Sastra Indonesia \\ Fakultas Ilmu Budaya, Universitas Jambi, Jambi, Indonesia \\ Pos-el: rengki_afria@unja.ac.id
}

\begin{abstract}
Abstrak
Penelitian ini menganalisis perbedaan-perbedaan kecil dalam sebuah dialek/ bahasa dengan teori dialektologi. Tujuan penelitian ini adalah menjelaskan variasi-variasi fonologis, merekonstruksi fonologis, menjelaskan inovasi dan retensi yang terdapat pada isolek Pulaupandan, Pengasi dan Muak. Penelitian deskriptif ini bersifat sinkronis dan diakronis dengan pendekatan secara kualitatif-kuantitatif. Metode Pengumpulan data menggunakan metode cakap dan metode simak. Analisis data menggunakan metode padan fonetis artikulatoris dengan teknik pilah sebagai teknik dasar serta teknik hubung banding sebagai teknik lanjutan, sedangkan untuk menentukan status kebahasaan dan persentase kekerabatan digunakan metode dialektometri. Penyajian hasil analisis data digunakan metode formal dan metode informal. Berdasarkan hasil analisis sinkronis ditemukan variasivariasi bunyi, yakni $[a],[a ?],[i],[u],[e],[\partial],[o],[o ?],[a w],[e w],[i y],[p],[b],[t],[k],[g],[m],[n]$, $[\eta],[n],[s],[d],[h],[?]$, dan $[l]$ dalam beberapa posisi. Berdasarkan hasil analisis diakronis ditemukan fonem PIBK dari hasil proses rekonstruksi protobahasa pada posisi tertentu. Fonem tersebut berupa enam fonem vokal dua gugus bunyi, yaitu vokal $* / i /, * / u /, * / e /$, $* / \partial /, * / o /$ dengan luncuran gugus bunyi $/ o ? /$, dan * $/ a /$ dengan meluncurkan gugus bunyi /a?/ ; tujuh diftong */aw/, */ow/, */ew/,*/iw/, */uw/ dan*/iy/, */oy/ dan sembilan belas fonem konsonan $* / p /, * / b /, * / t /, * / k /, * / g /, * / m /, * / n /, * / \eta /, * / n /, * / s /, * / d /, * / h /, * / P /$, $* / l /, * / r /, * / j /, * / c /, * / w /$, dan $* / y /$. Inovasi fonologis yang ditemukan berdasarkan kaidah perubahan bunyi, seperti: 1) metatesis; 2) afaresis; 3) pemecahan vokal; 4) apokop; dan 5) sinkop. Berdasarkan bukti-bukti sinkronis dan diakronis dengan menggunakan metode dialektometri serta hasil analisis data yang didapatkan di lapangan, IPp dinyatakan sebagai titik pengamatan yang masih mempertahankan isoleknya (konservatif).
\end{abstract}

Kata Kunci: variasi, rekonstrusi, fonologi, dialektologi

\begin{abstract}
This research analyzed the small differences on dialect/language based on dialectology. The aims of this research are to explain the phonological variation, to reconstruct the phonological, and explain the phonological inovations and retentions found in Pulaupandan, Pengasi and Muak isolect. This descriptive study belongs to synchronic and diachronic with qualitative-quantitative approaches. The collecting of data used conversational method and participant observational method. Data analysis used phonetic articulatory method with sorting techniques as basic technique and comparatingconnecting techniques as advanced techniques, while to determine the status of language and kinship percentage used dialectometry method. Presenting of data analysis results used formal and informal methods. Based on of the results analysis found variations synchronyc sounds, are, [a], [a?], [i], [u], $[e],[\partial],[o],[o P],[a w],[e w],[i y],[p],[b],[t],[k],[g],[\mathrm{m}],[\mathrm{n}],[\eta],[n],[s],[d],[\mathrm{h}],[?]$, and $[\mathrm{l}]$ in some positions. Based on the results of analysis diachronic found PIBK protolanguage phoneme from
\end{abstract}


reconstruction process results in a certain position. That Phonemes form six vowels and two cluster sounds, they are; */i/, */u/, */e/, */o/, */o/ with a glide group sound /oP/, and */a/ with launched cluster sound /aP/; seven diphthong */aw/, */ow/, */ew/, */iww/, */uw/ and */iy/, */oy/ and nineteen consonant phonemes */p/,*/b/,*/t/,*/k/,*/g/,*/m/,*/n/,*/l/,*/n/,*/s/,*/d/,*/h/,*/P/,*/l/,*/r/,*/j/,*/c/,*/w/, and $* / y /$. Phonological inovations were found based on the rules of sound changes, such as: 1) metathesis; 2) aphaeresis; 3) vowels breaking; 4) apocope; and 5) of syncope. Based on the evidences of synchronic and diachronic with used dialectometry method and the results of the analysis of data obtained in the field, IPp expressed as an observation point which still retain its isolect (conservative).

Keywords: variation, recontruction, phonology, dialectology

\section{PENDAHULUAN}

Isolek Kerinci memiliki berbagai macam variasi. Walaupun demikian, isolek-isolek tersebut memiliki perbedaan, baik dalam tataran fonologis maupun leksikal antarisolek. Akan tetapi, penutur dan lawan tutur saling memahami dan mengerti (mutual intelligible) ketika mereka menuturkan isolek masing-masing sehingga tidak menghambat bagi masyarakat Kerinci untuk melakukan kontak komunikasi satu sama lain.

Isolek-isolek tersebut berdasarkan tinjauan lapangan diasumsikan dapat berbeda-beda pada setiap kecamatan atau desa yang ada di Kabupaten Kerinci, salah satunya adalah isolek Kecamatan Bukitkerman Kabupaten Kerinci yang menjadi daerah pengamatan dalam penelitian ini. Pemilihan Kecamatan tersebut beralasan salah satunya bahwa desa-desa yang dijadikan titik pengamatan berada pada kecamatan itu. Adapun desa yang dititikberatkan sebagai titik pengamatan penelitian ini adalah isolek 3 desa, yaitu Desa Pulaupandan, Pengasi, dan Muak. Pemilihan daerah tersebut didasarkan kriteria pemilihan daerah penelitian yang dikemukakan oleh Ayatrohaedi (1979: 35) dan Nadra dan Reniwati (2009: 45) bahwa keadaan letak geografis yang berdekatan dan tinjauan sejarah bahwasanya ketiga desa tersebut berasal dari satu keturunan yang sama

Setiap isolek yang ada di daerah tersebut dijumpai adanya unsur-unsur yang telah mengalami perubahan dan pembaharuan dari bahasa ibunya (protobahasa). Proses perubahan tersebut berlangsung secara perlahan dari masa ke masa. Perubahan dan pembaharuan ter- sebut tidak hanya berasal dari pengaruh luar isolek, tetapi juga pengaruh di dalam isolek itu sendiri. Pengaruh tersebut dapat berupa pembaharuan pada unsur bunyi dan fonem yang ada di dalam isolek itu sendiri maupun pembaharuan dengan meyerap unsur bunyi dari luar isolek dari daerah yang berdekatan dengan isolek tersebut.

Variasi-variasi isolek daerah yang diteliti dapat dilihat beberapa keunikan keragaman isoleknya. Selanjutnya, variasi tersebut direkonstruksi sehingga dapat ditemukan bentuk proto isolek dari isolek tersebut. Kemudian, hasil rekonstruksi dapat dipilah bentuk yang inovatif dan konservatif, dan terakhir dihitung persentase dengan pendekatan dialektometri untuk dapat dianalisis status kebahasaan. Berdasarkan latar belakang tersebut sangat menarik untuk dikaji variasi dan rekonstruksi fonologis isolek kerinci: studi dialektologi diakronis di Kecamatan Bukit Kerman.

Penelitian ini merujuk kepada beberapa jurnal ilmiah terakreditasi, baik nasional maupun internasional sebagai kajian literatur terdahulu. Penelitian tersebut adalah jurnal Makara, Sosial Humaniora, Vol 12, No. 1 oleh Nadra, dkk (2008) dengan judul Daerah Asal Dan Arah Migrasi Orang Minangkabau Di Provinsi Jambi Berdasarkan Kajian Variasi Dialektal. Penelitian tersebut berupaya untuk menelusuri daerah asal dan arah migrasi orang Minangkabau yang berada di Provinsi Jambi berdasarkan kajian variasi dialektal. Metode yang digunakan yakni metode dialektometri dengan teknik permutasi. Berdasarkan perhitungan tersebut, di Provinsi Jambi ditemukan lebih banyak ke- 
cenderungan asal dan arah migrasi. Titik pengamatan-titik pengamatan (TP-TP) Jambi yang memperlihatkan hubungan beda wicara dengan TP-TP Sumatera Barat yang mempunyai tiga pola kecenderungan asal dan arah migrasi, sedangkan TP-TP yang menunjukkan tingkat hubungan pada perbedaan subdialek menunjukkan lebih banyak kecenderungan asal dan arah migrasi, yakni tujuh pola. Llamzon (1975) dengan judul artikel Proto-Philippine Phonology yang upaya merekonstruksi Proto-Filipina pada kajian Fonologi yang berdasarkan bukti dari sembilan bahasa. Llamzon hanya melakukan tahap pertama dari tiga tahap penelitian. Kesimpulan yang dicapai dalam tahap pertama akan diuji dalam tahap kedua dengan bukti dari bahasa Filipina lainnya untuk melihat apakah fonem bahasa itu dapat ditelusuri kembali ke protofonem yang telah direkonstruksi sampai saat ini. Tahap ketiga dari penelitian tersebut membangun hubungan antara pengelompokan bahasa-bahasa tersebut. Selain itu, Sastra (1994) melakukan penelitian tentang "Protobahasa Minangkabau - Kerinci: Rekonstruksi Fonologi". Hasil penelitian tersebut secara umum diuraikan bahwa bahasa-bahasa dan dialek Lpk, Tdy, Agm, Prm, Psr, Ktb, Psm, $K h l, K t h$ dan $K h r$ yang wilayah pakainya di daerah Sumetera Bagian Tengah, khususnya di Provinsi Sumatera Barat dan di Kabupaten Kerinci Provinsi Jambi adalah satu kelompok bahasa sekerabat yang disebut "Kelompok bahasa Minangkabau-Kerinci", sebagai salah satu anggota kelompok Bahasa Melayo Polinesia Barat.

Berdasarkan penelitian-penelitian terdahulu tersebut tentu saja berbeda dari penelitian ini dialektologi ini. Cakupan-cakupan penelitian dan hasil yang didapatkan sangat berbeda mesikipun teori yang dikemukakan mempunyai sedikit kesamaan.

Dengan demikian, tujuan penelitian ini adalah berupaya untuk menjawab pertanyaanpertanyaan penelitian: Bagaimanakah variasi dan rekonstruksi fonologis dalam melihat ino- vasi dan retensi di Kecamatan Bukitkerman, Kabupaten Kerinci?

\section{TEORI DAN METODE}

Teori-teori yang digunakan dalam penelitian ini adalah teori dialektologi diakronis seperti yang telah dikemukakan para ahli bidang ilmu dialektologi. Mahsun (1995:11) mengemukakan bahwa pada dasarnya dialektologi merupakan ilmu tentang dialek; atau cabang dari linguistik yang mengkaji perbedaan-perbedaan isolek dengan memperlakukan perbedaan tersebut secara utuh. Nadra (2006:28) mengemukakan bahwa dialektologi merupakan salah satu cabang linguistik (ilmu bahasa) yang mengkaji dialek dan dialek-dialek. Dengan kata lain, dialektolgi dapat mengkaji dialek tertentu saja dari suatu bahasa dan dapat pula mengkaji dialek-dialek yang ada dalam bahasa. Dialektologi juga dapat mengkaji perbedaan-perbedaan atau variasi-variasi isolek. Secara diakronis, dialektologi merupakan suatu kajian perbedaan-perbedaan isolek yang bersifat analitis sinkronis dengan menafsirkan perbedaan-perbedaan isolek tersebut berdasarkan kajian yang bersifat historis atau diakronis.

Nadra dan Reniwati (2009: 23), Mahsun (1995: 28) variasi atau perbedaan fonologi yang dimaksud menyangkut variasi bunyi dan variasi fonem. Variasi tersebut digolongkan pada beberapa perubahan bunyi yang dikemukakan oleh Crowley (1992: 39 59) yang berupa variasi adalah: lenisi (pelemahan) yang mencakup Cluster reduction (penghilangan gugus konsonan), apokope, sinkope, haplology, dan aphaeresis; sound Addition (PenambahanBunyi) yang mencakup; Ekskrensen, anaptaksis, dan protesis; metatesis, fusi unpacking (pemisahan), vowel breaking (Pemecahan Vokal) asimilasi, disasimilasi. Proses rekonstruksi menggunakan teori rekonstruksi bahasa purba yang telah dikemukakan oleh Fox (1995: 13), Mahsun (1995: 73), dan Nadra (2006: 102). Teori tersebut berupaya penyusunan kembali sosok bahasa 
purba yang menurunkan isolek-isolek modern yang digunakan oleh penutur-penutur pada masa sekarang.

Dengan adanya rekonstruksi bahasa purba dapat pula diketahui apakah bahasa-bahasa/ dialek-dialek modern atau yang digunakan penutur saat ini mengalami inovasi atau retensi. Simbol-simbol bunyi vokal dan konsonan dalam hal merekonstruksi, digunakan simbolsimbol yang mengacu pada International Phonetic Alphabet (IPA) yang dipublikasikan dan direvisi oleh P.W. Schmidt (Kemp, J. A, 2006: 408). Perbandingan fonem Proto-malayik (PM) diadopsi dari Adelaar (1992: 244 - 259) dan Nadra (2006: 134 - 155).

Penganalisisan unsur-unsur inovasi pada penelitian ini mengadopsi teori Hock (1988: 581) yang sesuai dengan unsur warisan dari bahasa asal yang telah mengalami perubahan pada bahasa sekarang. Sedangkan retensi menggunakan teori Mahsun (1995: 91 92) dalam upaya penelusuran evidensi pewarisan etimon bahasa purba dalam dialek atau subdialek bahasa yang diteliti.

Data yang diambil dalam penelitian ini adalah data yang bersumber dari sumber lisan dan sumber tulisan. Data penelitian ini adalah bunyi-bunyi isolek Kerinci di Kecamatan Bukitkerman yang didasarkan 738 kosakata. Sumber data penelitian ini terdiri atas sumber data substantif dan sumber data lokasional (Sudaryanto, 1988, hlm. 26). Sumber data substantif atau sampel diperoleh pada wilayah isolek Kecamatan Bukitkerman dan sumber data lokasional Sumber data lokasional penelitian ini bersumber dari tiga informan pada setiap TP tersebut.

Metode dan teknik penyediaan data dalam penelitian bahasa secara diakronis adalah dengan menggunakan metode cakap dan metode simak. Metode cakap memiliki teknik dasar berupa teknik pancing dan teknik cakap semuka sebagai teknik lanjutan (Mahsun 2005:121, Sudaryanto, 1993:137). Metode simak dalam mengumpulkan data menggunakan teknik simak libat cakap. Pelaksanaan teknik ini ditunjang dengan teknik rekam dan teknik catat. Simbol-simbol fonetis yang digunakan adalah mengacu pada International Phonetic Alphabet (IPA) yang dipublikasikan dan direvisi oleh P.W. Schmidt (Kemp, J. A, 2006: 408).

Metode analisis data dalam penelitian ini menggunakan metode padan (Sudaryanto, 1993: 13, 23 27) dan metode dialektometri (Ayatrohaedi, 1979: 31; Mahsun, 1995:118; Nadra dan Reniwati, 2009:91). menggunakan metode padan fonetis artikulatoris dengan teknik pilah sebagai teknih dasar, sedangkan teknik lanjutannya adalah teknik hubung banding penyamaan (HBS) dan teknik hubung banding membedakan (HBB) serta ditambah dengan teknik hubung banding membedakan hal pokok (HBBP) untuk melihat variasi atau perbedaannya.

Adapun rumus yang digunakan dalam dialektometri dalam tataran fonologis ialah sebagai berikut; (Teori ini dipakai oleh beberapa ahli dialektologi seperti; Ayatrohaedi (1979: 91), Mahsun (1995: 118), Nadra dan Reniwati (2009: 92).

$$
\frac{(S x 100)}{n}=d \%
$$

$S=$ jumlah beda dengan DP lain

$\mathrm{n}$ = jumlah peta yang dibandingkan

$d=$ jarak kosakata dalam persentase

Perbedaan dalam tataran fonologis:

$17 \%$ ke atas : perbedaan bahasa

$12 \%-16 \% \quad$ : perbedaan dialek

$8 \%-11 \% \quad$ : perbedaan subdialek

$4 \%-7 \% \quad$ : perbedaan wicara

$0 \%-3 \% \quad$ : tidak ada perbedan

Analisis kuantitatif digunakan sebagai analisis lebih lanjut dalam penentuan dialek atau subdialek yang inovatif dan konservatif dilakukan dengan menghitung presentase kemunculan bentuk-bentuk yang telah 
ditentukan sebagai bentuk yang inovatif dan konservatif tersebut. Rumus yang digunakan berdasarkan Mahsun (1995: 147) adalah:

\section{$\Sigma \mathbf{m} / \mathbf{p} \times 100 \%$}

Catatan :

$\mathrm{m}=$ Jumlah bentuk inovasi atau retensi yang muncul pada masing-masingdialek, subdialek, atau daerah-daerah pengamatan.

$\mathrm{p}=$ Jumlah keseluruhan bentuk inovasi dan retensi yang dijadikanpercontoh.

Penyajian hasil analisis data dengan menggunakan Lambang yang bersumber dari International Phonetic Alphabet (IPA) yang dipublikasikan dan direvisi oleh P.W. Schmidt (Kemp, J. A, 2006: 408). Tanda atau lambang yang digunakan adalah; Tilde ( ); Asterisk $\left(^{*}\right)$; (>) menjadi; (<) berasal dari; (\#)batas kata; ([ ]) transkripsi fonetis; (/ / ) transkripsi fonemis; (/ ) lingkungan; (-)posisi unsur dalam kata; dan (' ') pengapit makna suatu unsur atau terjemahan. Selain itu, terdapat juga huruf-huruf singkatan, misalnya; isolek Kecamatan Bukitkerman (IBk), isolek Pulaupandan (IPp), isolek Pengasi (IP), dan isolek Muak (IM). Tidak hanya itu, hasil penelitian juga dituangkan ke dalam tabel, diagram, dan bagan.

\section{HASIL DAN PEMBAHASAN}

Bahasa Kerinci merupakan bahasa Melayu yang berkerabat dengan bahasa daerah yang ada di dekatnya, yaitu bahasa Minangkabau dan bahasa Melayu Tengah. Dialek Kerinci merupakan salah satu dialek yang termasuk ke dalam rumpun bahasa Austronesia dan merupakan bagian dari kelompok Proto-melayik (Proto-Malayic). Bahasa-bahasa tersebut berada pada tingkat sejajar dan tidak menunjukkan hubungan saling menurunkan antara bahasa yang satu dengan bahasa yang lain. Hal ini bermaksud bahwa bahasa Melayu, Minangkabau, Melayu Tengah, dan isolek Kerinci memiliki status yang sama sebagai turunan langsung dari Malayan Sub-family.

\section{Variasi Bunyi Vokal, Diftong, dan Konsonan}

Variasi vokal merupakan variasi-variasi vokal yang terdapat pada titik pengamatan di Kecamatan Bukitkerman (IPp, IP, dan IM). Variasi-variasi tersebut adalah bunyi $[a]$ yang meluncurkan bunyi gugus [a?], bunyi [i], [u], $[\partial],[e],[o]$ yang juga meluncurkan gugus bunyi [o?].

Variasi bunyi vokal yang muncul adalah: variasi $[a] \sim[\varnothing] / \#-;$ variasi $[a] \sim[$ ] $]$ / antepenultima; variasi $[a] \sim[o] /-h \#$; variasi $[a] \sim[e a] \sim[a i] \sim[i a] \sim[a e] \sim[a u] \sim[a o] /-\# \mathrm{~K} ;$ variasi $[e]$ dan $[a]$ / penultima; variasi [a?] [o?] / -\#; variasi $[i] \sim[\varnothing] / \#-;$ variasi $[i] \sim[e] /$ ultima; variasi $[u] \sim[\varnothing] / \#-;$ variasi $[u] \sim[$ oic $]$ dan $[o] /-h \#$; variasi $[ə] \sim[\varnothing] / \#-;$ variasi $[\partial]$ $\sim[i y]$ / -\#; variasi $[ə] \sim[e a] /$ ultima; variasi $[e]$ $\sim[e a] /$-\#; variasi $[e] \sim[a y] /$-\#; variasi $[o] \sim$ $[e o],[o u] /$-\#; variasi $[o] \sim[a o] /$-\#; variasi $[o]$ $\sim[a o] \sim[e o] \sim[o u] \sim[o i c h] /$-K\#; variasi [o?] [u?] / -\#.

Sementara itu, variasi bunyi diftong memunculkan variasi $[a w] \sim[o w] / \#$; variasi $[e w] \sim[i w] \sim[u w] /$-\#; variasi $[\partial y] \sim[i y] /$-\#; serta variasi bunyi konsonan yang memunculkan variasi $[p] \sim[\varnothing] / \#$-; variasi $[p]$ $\sim[$ ?] / -\#; variasi $[p] \sim[?] \sim[t] /$-\#; variasi $[p]$ $\sim[b] \sim[t] /$-\#; variasi $[b] \sim[\varnothing] / \#-$ dan variasi $[b] \sim[p] / \#-;$ variasi $[t] \sim[p] /$-\#; variasi $[t] \sim[?] /$-\#; variasi $[g] \sim[\varnothing] /$ \#-; variasi $[k] \sim[\varnothing] / \#-;$ variasi $[g] \sim[k] /$ \#-; variasi $[m] \sim[\varnothing] / \#-,-\#$; variasi $[n] \sim[\varnothing] /$-\#; variasi $[n] \sim[s] / \#-;$ variasi $[\eta] \sim[\varnothing] /$-\#; variasi $[\eta] \sim[\varnothing] /$ \#-; variasi $[\eta] \sim[k] /$ \#-; variasi $[s] \sim[/][z] /$ penultima; variasi $[d] \sim$ $[\varnothing] /$ \#-; variasi $[n] \sim[c]$ dan $[n] \sim[j] /$ \#-; variasi [?] $\sim[t] /-\#$; variasi /l/ $\sim[n] /$-\#; variasi $[l]$ dan $[\varnothing]$ / \#- dan variasi $[l] \sim[\varnothing]$ / $\#$.

Dari keseluruhan data bunyi tersebut (738) ditemukan 25 unsur perbedaan fonologis atau $3.38 \%$ dari keseluruhan unsur yang menunjukkan perbedaan fonologis dalam tiga isolek titik pengamatan yang diteliti. 
Hasil tersebut dijadikan dasar dalam penentuan status kebahasaan ketiga isolek titik pengamatan di Kecamatan Bukitkerman Kabupaten Kerinci, yaitu tidak ada perbedaan. Selanjutnya, jumlah perbedaan fonologis yang muncul antartitik pengamatan adalah 0 perbedaan unsur fonologis titik pengamatan IPp dan IP; IP dan IM sebesar 2 unsur; dan 2 unsur fonologis dalam IM dan IPp.

Tabel 1. Persentase Jarak Perbedaan Fonologis Antartitik Pengamatan

\begin{tabular}{|c|c|c|}
\hline $\begin{array}{c}\text { Isolek Antartitik } \\
\text { Pengamatan }\end{array}$ & $\begin{array}{c}\text { Jarak Fonologis dalam } \\
\text { Persentase }\end{array}$ & Keterangan Status Kebahasaan \\
\hline IPp dan IP & $0 \%$ & Tidak ada perbedaan \\
\hline IP dan IM & $0.27 \%$ & Tidak ada perbedaan \\
\hline IM dan IPp & $0.27 \%$ & Tidak ada perbedaan \\
\hline
\end{tabular}

\section{Bentuk-bentuk Rekonstruksi}

Hasil rekonstruksi di atas, diperoleh perangkat korespondensi bunyi yang didasarkan dari International Phonetic Alphabet (IPA) yang dipublikasikan dan direvisi oleh P.W. Schmidt (Kemp, J. A, 2006: 408) di atas, terdapat beberapa korespondensi bunyi yang digunakan di Kecamatan Bukit Kerman, Kabupaten Kerinci, diperoleh bentuk protofonem isolek Kecamatan Bukitkerman (PIBK).

Rekonstruksi fonem vocal didapatkan PIBK *a / penultima $(<\mathrm{PM}$ *a) $>$ semua isolek $a$; PIBK *a / \#- (<PM *a) > IPp a, IP dan IM $a$, Ø; PIBK *a / antepenultima (<PM *a) $>$ IPp, IP dan IM $a, a ;$ PIBK *a / -h\# (<PM *a) $>$ IPp dan IP $a, o, \operatorname{IM} a$; PIBK *a /-\#K (<PM *a) > IPp $a, a i, a u ;$ IP ea, ao, ae, a; IM a,ia,ou.; PIBK *a / -?, $\mathrm{t}(<\mathrm{PM} * \mathrm{a})>\operatorname{IPp}$ dan IM $a$, IP $e ;$ PIBK *a / penultima ( $<\mathrm{PM} *$ a) $>\operatorname{IPp} e$, IP dan IM $a$; PIBK *a? / -\# (< PM *a?) > IPp o?, IP dan IM $a$; PIBK $*_{\mathrm{i}} /$ penultima $\left(<\mathrm{PM} *_{\mathrm{i}}\right)>$ semua isolek I; PIBK *i / \#- $(<$ PM *i) $>$ IPp $i$, IP dan IM $\varnothing$, PIBK *i / ultima $(<$ PM *i $)>$ IPp dan IP $i$, IM $e$; PIBK *u / penultima $(<\mathrm{PM} * \mathrm{u})>$ semua isolek $u$; PIBK *u / \#- $\left(<\mathrm{PM}{ }^{*} \mathrm{u}\right)>\mathrm{IPp}$, $\mathrm{IP}$, dan IM $u, \varnothing ;$ PIBK *u / \# -h $\left(<\mathrm{PM}{ }^{*} \mathrm{u}\right)>$ IPp $u$, IP $, u, o, \operatorname{IM} u, o i c ;$ PIBK *ə / ultima, ante penultima $\left(<\mathrm{PM}{ }^{*} \partial\right)>$ semua isolek $\partial$; PIBK *ə / \#- (< PM *ə) > IPp ə, IP dan IM Ø; PIBK *ə /
-\# ( < PM *a) > IPP dan IP ə, IM iy; PIBK *ə / ultima $\left(<\mathrm{PM}{ }^{*}\right.$ ) $)>$ IPP $a$, IP dan IM ea; PIBK *e / ultima $\left(<\mathrm{PM}{ }^{*} \mathrm{e}\right)>$ semua isolek $e$; PIBK *e / -\# ( < PM *e) > IPp dan IP e, ea; IM ea; PIBK *o / -\# (< PM*a) > semua isolek $o$; PIBK *o / -\# ( < PM *a) > IPp o, IP eo, IM o, ou; PIBK ${ }^{*} \mathrm{O} /$-\# $(<\mathrm{PM} * \mathrm{a})>\mathrm{IPp}, \mathrm{IP}$, dan IM $o, a o$; PIBK ${ }^{*} \mathrm{O} /$-K\# (< PM *a) > IPp oa, o; IP o, ao, eo, eu, eo; IM ou, o, ao, eo, eu, oic; PIBK *o? / -\# (< PM *u?) > IPp u?, IP dan IM o?

Rekonstruksi Diftong PIBK; PIBK *aw / \# / ( < PM *aw) > IPp dan IP aw, IM ow; PIBK *ew / -\# ( < PM *uw) > IPp ew, IP iw, IM uw; PIBK *iy / -\# (< PM *iy) > IPp əy, IPp dan IM iy.

Rekonstruksi Fonem Konsonan PIBK; PIBK * $\mathrm{p} / \#-$, ultima $\left(<\mathrm{PM}{ }^{*} \mathrm{p}\right)>$ semua isolek $p$; PIBK *p / \#- $\left(<\mathrm{PM}{ }^{*} \mathrm{p}\right)>\mathrm{IPp}$ dan IM $\varnothing$, IP $p ;$ PIBK * p / -\# (< PM *p) > IPp, IP, dan IM $p$, P; PIBK *b / \#-, ultima ( $\left.<\mathrm{PM}{ }^{*} \mathrm{~b}\right)>$ semua isolek $b$; PIBK *b / \#- $(<\mathrm{PM} * \mathrm{~b})>\operatorname{IPp} b, \operatorname{IP} b$, $\varnothing$, IM $\varnothing ;$ PIBK *t / \#-, ultima $\left(<\mathrm{PM}{ }^{*} \mathrm{t}\right)>$ semua isolek $t$. PIBK *t / \#- $\left(<\mathrm{PM}{ }^{*} \mathrm{t}\right)>\mathrm{IPp}$ dan IM $t$, IP P; PIBK *k / \#-, penultima, ultima $\left(<\mathrm{PM}{ }^{*} \mathrm{k}\right)>$ semua isolek $k$; PIBK ${ }^{*} \mathrm{k} / \mathrm{\# -}(<$ $\left.\mathrm{PM}^{*} \mathrm{k}\right)>\operatorname{IPp} k, \varnothing$, IP $k, \varnothing$, IM $\varnothing ;$ PIBK *k / \#$\left(<\mathrm{PM}^{*} \mathrm{~g}\right)>\mathrm{IPp} g$, IP dan IM $k$; PIBK *g / \#-, ultima $\left(<\mathrm{PM}{ }^{*} \mathrm{~g}\right)>$ semua isolek $g ;$ PIBK *g / \#- $\left(<\mathrm{PM}{ }^{*} \mathrm{~g}\right)>\operatorname{IPp} g$, IP $g, \varnothing$, IM $\varnothing ;$ PIBK *m / \#-, ultima $\left(<\mathrm{PM}^{*} \mathrm{~m}\right)>\mathrm{IPp}$, IP, dan IM $m$; PIBK ${ }^{*} \mathrm{~m} /$-\#- $\left(<\mathrm{PM}{ }^{*} \mathrm{~m}\right)>\mathrm{IPp}$ dan IM $m$, IP $\varnothing$; PIBK *n / -\#, ultima $\left(<\mathrm{PM}^{*} \mathrm{n}\right)>$ semua isolek $n$; PIBK *n / -\# (<PM *n) > IPp n, IP n, Ø, IM, $\varnothing, n ;$ PIBK * $\eta /$-\# (<PM * $\eta)$ semua isolek $\eta$; PIBK * $\eta /$-\# (<PM * $\eta)>\operatorname{IPp} n$, IP dan IM $n, \eta$; PIBK* ${ }^{*} /$-\#- $\left(<\mathrm{PM}{ }^{*} \eta\right)>\mathrm{IPp}, \mathrm{IP}$, dan IM $\eta, \varnothing$; PIBK * $\eta / \#-\left(<P M{ }^{*} \eta\right)>\operatorname{IPp} k, \eta$, IP $k$, IM $\eta ;$ PIBK *s / \#- $\left(<P M{ }^{*} \mathrm{~S}\right)>$ semua isolek $s$; PIBK ${ }^{*} \mathrm{~S} /$ ultima $\left(<\mathrm{PM}{ }^{*} \mathrm{~s}\right)>\operatorname{IPp}$ dan IP s, IM $\int, z$; PIBK *d / \#-, ultima $\left(<\mathrm{PM}{ }^{*} \mathrm{~d}\right)>$ semua isolek $d$; PIBK *d / \#- $(<\mathrm{PM} * \mathrm{~d})>\operatorname{IPp} d, \mathrm{IP} d, \varnothing, \mathrm{IM}$ $\varnothing ;$ PIBK *h / -\#-, ultima $\left(<\mathrm{PM}{ }^{*} \mathrm{~h}\right)>$ semua isolek $h$; PIBK *h / -\#- (<PM *r) $>\operatorname{IPp} h, \varnothing$, IP $\varnothing, \mathrm{IM} h$; PIBK *h $(\mathrm{h} \sim \varnothing) / \mathrm{V}-\mathrm{V}\left(<\mathrm{PM}{ }^{*} \mathrm{r}\right) \mathrm{IPp}$ dan IP $\varnothing, \operatorname{IM} h ; \mathrm{PIBK}^{*} \mathrm{n} /$ \#- $\left(<\mathrm{PM} *_{\mathrm{n}}\right)>\operatorname{IPp} c$, 
IP dan IM $n$; PIBK *n / \#-, ultima $\left(<\mathrm{PM}^{*} \mathrm{n}\right)>$ semua isolek $n$; PIBK *? / -\# (<PM *?) $>$ IPp dan IP ?, IM $t$; PIBK *1 / \#-, ultima $(<\mathrm{PM} * 1)>$ semua isolek $l$; PIBK *l $/$-\#- $\left(<\mathrm{PM}{ }^{*} \mathrm{l}\right)>\mathrm{IPp}$, $\mathrm{IP}$, dan IM l, Ø; PIBK * ${ }^{*} /$ \#- $\left(<\mathrm{PM}{ }^{*} \mathrm{~W}\right)>\mathrm{IPp}$ $w$, IP dan IM Ø; PIBK * ${ }^{*} /$ ultima $\left(<\mathrm{PM}{ }^{*} \mathrm{~W}\right)>$ IPp, IP, dan IM w; PIBK *y / ultima (<PM *y) $>$ semua isolek $y ; \mathrm{PIBK}^{*} \mathrm{r} /$ \#-, ultima dan penultima $\left(<\mathrm{PM}{ }^{*} \mathrm{r}\right)>\mathrm{IP}, \mathrm{IPP}, \mathrm{IM} r$; PIBK *j / \#-, ultima $\left(<\mathrm{PM} *_{\mathrm{j}}\right)>$ semua isolek $j$; PIBK ${ }^{*} \mathrm{C} /$ \#-, ultima $\left(<P M{ }^{*} \mathrm{C}\right)>$ semua isolek $c$.

Rekonstruksi-rekonstruksi fonem vokal, konsonan, dan diftong tersebut dijelaskan terperinci dalam table berikut.

Tabel 2.

Inventarisasi Konsonan PIBK

\begin{tabular}{|c|c|c|c|c|c|c|c|c|}
\hline & & 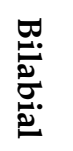 & 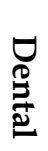 & $\begin{array}{l}\stackrel{D}{4} \\
\stackrel{1}{1} \\
\stackrel{0}{0} \\
\stackrel{2}{2}\end{array}$ & 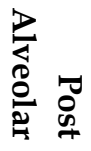 & $\begin{array}{l}\mathbb{D} \\
\stackrel{2}{D} \\
\stackrel{D}{D}\end{array}$ & $\frac{\overleftrightarrow{a}}{2}$ & $\frac{\Omega}{\frac{Q}{\Phi}}$ \\
\hline \multirow{3}{*}{ Hambat } & TB & ${ }^{*} p$ & \multirow{3}{*}{\multicolumn{3}{|c|}{${ }^{*} \mathrm{~d}$}} & & ${ }^{*} \mathrm{k}$ & $* ?$ \\
\hline & & & & & & & & \\
\hline & B & ${ }^{*} b$ & & & & & ${ }^{*} \mathrm{~g}$ & \\
\hline Nasal & B & ${ }^{*} \mathrm{~m}$ & \multicolumn{3}{|c|}{${ }^{*} \mathrm{n}$} & ${ }^{*} \mathrm{n}$ & ${ }^{*} \eta$ & \\
\hline Trill & B & & \multicolumn{3}{|c|}{${ }^{{ }^{*} \mathrm{r}}$} & & & \\
\hline \multirow{3}{*}{ Frikatif } & TB & & & $*_{S}$ & & & & ${ }^{*} \mathrm{~h}$ \\
\hline & & & & & & & & \\
\hline & B & & & ${ }^{*} \mathrm{Z}$ & ${ }^{*} 5$ & & & \\
\hline \multirow[t]{3}{*}{ Afrikatif } & TB & & & & & ${ }^{*_{C}}$ & & \\
\hline & & & & & & & & \\
\hline & B & & & & & $*_{j}$ & & \\
\hline Literal & B & & & ${ }^{* 1}$ & & & & \\
\hline Semivokal & B & ${ }^{*} \mathrm{~W}$ & & & & ${ }^{*} \mathrm{y}$ & & \\
\hline
\end{tabular}

Tabel 3.

Inventarisasi Fonem Vokal PIBK

\begin{tabular}{|c|c|c|c|c|c|c|c|}
\hline & & \multicolumn{2}{|c|}{ Depan } & \multicolumn{2}{|c|}{ Pusat } & \multicolumn{2}{|c|}{ Belakang } \\
\hline & & Hampar & bulat & Hampar & Bulat & hampar & Bulat \\
\hline Tinggi & $\begin{array}{l}\text { tertutup } \\
\text { terbuka }\end{array}$ & $*_{i}$ & & & & & ${ }^{*} \mathrm{u}$ \\
\hline Tengah & $\begin{array}{l}\text { tertutup } \\
\text { terbuka }\end{array}$ & ${ }^{*} \mathrm{e}$ & & *a & & & ${ }^{*} \mathrm{O}$ \\
\hline Rendah & $\begin{array}{l}\text { tertutup } \\
\text { terbuka }\end{array}$ & *a & & & & & \\
\hline
\end{tabular}


Hasil rekonstruksi didapatkan bentukbentuk fonem proto yang mengalami refleksi pada bentuk sekarang. Bentuk-bentuk tersebut muncul dalam beberapa posisi berdasarkan lingkungan seperti: pada posisi penultima, ultima, awal kata, akhir kata, awal dan akhir kata, antepenultima.
Selanjutnya, dari semua hasil rekonstruksi fonem PIBK di atas berdasarkan PM, dapat dibuat hubungan kekerabatan PIBK dan PM. Hasil tersebut disajikan dalam tabel di bawah ini.

Tabel 4.

Fonem PM, Fonem PIBK, dan refleknya dalam Bahasa Kerinci Isolek Kecamatan Bukitkerman

\begin{tabular}{|c|c|c|c|}
\hline PM & PIBK & $\begin{array}{c}\text { Isolek Kecamatan Bukit kerman } \\
\text { (Isolek Pulau pandan, Pengasi, dan } \\
\text { Muak) }\end{array}$ & Keterangan \\
\hline *a & *a & $a$ & Penultima \\
\hline *a & *a & $a, \varnothing$ & \#- \\
\hline *a & *a & $a, \partial$ & Antepenultima \\
\hline *a & *a & $a, o$ & -h\# \\
\hline *a & *a & $e a, a o, a e, a, i a, o u, a i, a u$ & -\#K \\
\hline *a & *a & $a, e$ & $-?, \mathrm{t}$ \\
\hline *a & *a & $e, a$ & penultima \\
\hline *a(?) & *a? & $o ?, a ?$ & $-\#$ \\
\hline$*_{i}$ & ${ }^{*} \mathrm{i}$ & $i$ & Penultima \\
\hline$*_{\mathrm{i}}$ & $*_{i}$ & $i, \varnothing$ & \#- \\
\hline$*_{\mathrm{i}}$ & $*_{\mathrm{i}}$ & $i, e$ & Ultima \\
\hline${ }^{*} \mathrm{u}$ & ${ }^{*} \mathrm{u}$ & $u$ & Penultima \\
\hline${ }^{*} \mathrm{u}$ & ${ }^{*} \mathrm{u}$ & $u, \varnothing$ & \#- \\
\hline${ }^{*} \mathrm{u}$ & ${ }^{*} \mathrm{u}$ & $o, u$, oic & -h\# \\
\hline${ }^{*} \partial$ & *2 & $\partial$ & $\begin{array}{l}\text { antepenultima dan } \\
\text { penultima }\end{array}$ \\
\hline *ə & *2 & $\partial, \varnothing$ & \#-h \\
\hline *ə & *2 & $\partial, i y$ & $-\#$ \\
\hline *2 & *2 & $\partial, e a$ & Ultima \\
\hline${ }^{*} \mathrm{e}$ & *e & $e$ & Ultima \\
\hline *e & *e & $e, e a, e a$ & $-\#$ \\
\hline *a & $*^{*} \mathrm{O}$ & $o$ & $-\#$ \\
\hline *a & ${ }^{*} \mathrm{O}$ & $e 0, o, o u$ & $-\#$ \\
\hline *a & ${ }^{*} \mathrm{O}$ & $0, a 0$ & $-\#$ \\
\hline *a & ${ }^{*} \mathrm{O}$ & $o a, o, a o, e o, e u, e o$, ou, oic. & $-\mathrm{K} \#$ \\
\hline *u? & *o? & $u ?, o p$ & $-\#$ \\
\hline *aw & *aw & $a w, o w$ & $-\#$ \\
\hline *ew & *ew & $e w, i w, u w$ & $-\#$ \\
\hline *iy & *iy & $\partial y, i y$ & $-\#$ \\
\hline${ }^{*} \mathrm{p}$ & ${ }^{*} \mathrm{p}$ & $p$ & \#-, ultima \\
\hline
\end{tabular}




\begin{tabular}{|c|c|c|c|}
\hline${ }^{*} \mathrm{p}$ & ${ }^{*} \mathrm{p}$ & $\varnothing, p$ & \#- \\
\hline${ }^{*} \mathrm{p}$ & ${ }^{*} \mathrm{p}$ & $p, ?$ & $-\#$ \\
\hline *b & *b & $b$ & \#-, ultima \\
\hline *b & *b & $b, \varnothing$ & \#- \\
\hline$*_{\mathrm{t}}$ & $* t$ & $t$ & \#-, ultima \\
\hline$*_{\mathrm{t}}$ & $*_{\mathrm{t}}$ & $t, ?$ & \#- \\
\hline${ }^{*} \mathrm{k}$ & ${ }^{*} \mathrm{k}$ & $k$ & \#-, penultima, ultima \\
\hline${ }^{*} \mathrm{k}$ & ${ }^{*} \mathrm{k}$ & $k, \varnothing$ & \#- \\
\hline${ }^{*} \mathrm{~g}$ & ${ }^{*} \mathrm{k}$ & $g, k$ & \#- \\
\hline${ }^{*} \mathrm{~g}$ & ${ }^{*} \mathrm{~g}$ & $g$ & \#-, ultima \\
\hline${ }^{*} \mathrm{~g}$ & ${ }^{*} \mathrm{~g}$ & $g, \varnothing$ & \#- \\
\hline${ }^{*} \mathrm{~m}$ & *m & $m$ & \#-, ultima \\
\hline${ }^{*} \mathrm{~m}$ & ${ }^{*} \mathrm{~m}$ & $m, \varnothing$ & -\#- \\
\hline${ }^{*} \mathrm{n}$ & ${ }^{*} \mathrm{n}$ & $n$ & -\#, ultima \\
\hline${ }^{*} \mathrm{n}$ & ${ }^{*} \mathrm{n}$ & $n, \varnothing$ & $-\#$ \\
\hline *n & ${ }^{*} \eta$ & $\eta$ & $-\#$ \\
\hline${ }^{*} \eta$ & ${ }^{*} \eta$ & $\eta, \varnothing$ & -\#- \\
\hline${ }^{*} \eta$ & ${ }^{*} \eta$ & $k, \eta$ & \#- \\
\hline${ }^{*} \mathrm{~S}$ & ${ }^{*} \mathrm{~S}$ & $s$ & \#- \\
\hline${ }^{*} \mathrm{~S}$ & ${ }^{*} \mathrm{~S}$ & $s, \int, z$ & ultima \\
\hline${ }^{*} \mathrm{~d}$ & $* \mathrm{~d}$ & $d$ & \#-, ultima \\
\hline$* d$ & $* d$ & $d, \varnothing$ & \#- \\
\hline${ }^{*} \mathrm{~h},{ }^{*} \mathrm{r}$ & *h & $h$ & -\#-, ultima \\
\hline${ }^{*} \mathrm{r}$ & ${ }^{*} \mathrm{~h}$ & $\varnothing, h$ & $\mathrm{~V}-\mathrm{V}$ \\
\hline${ }^{*} \mathrm{r}$ & *h & $\varnothing, h$ & -\#- \\
\hline *n & ${ }^{*} \mathrm{n}$ & $c, n$ & \#- \\
\hline$* \mathrm{n}$ & $* \mathrm{n}$ & $n$ & \#-, ultima \\
\hline *? & *? & $P, t$ & -\# \\
\hline$* 1$ & $* 1$ & $l$ & \#-, ultima \\
\hline$* 1$ & *1 & $l, \varnothing$ & $-\#-$ \\
\hline${ }^{*} \mathrm{~W}$ & ${ }^{*} \mathrm{~W}$ & $w, \varnothing$ & \#- \\
\hline${ }^{*} \mathrm{~W}$ & ${ }^{*} \mathrm{~W}$ & $w$ & ultima \\
\hline${ }^{*} \mathrm{y}$ & ${ }^{*} \mathrm{y}$ & $y$ & ultima \\
\hline${ }^{*} \mathrm{r}$ & ${ }^{*} \mathrm{r}$ & $r$ & $\begin{array}{l}\text { \#-, ultima dan } \\
\text { penultima }\end{array}$ \\
\hline${ }^{*} \mathrm{C}$ & ${ }^{*} \mathrm{C}$ & $c$ & \#-, ultima \\
\hline${ }^{*} \mathrm{j}$ & ${ }^{*} \mathrm{j}$ & $j$ & \#-, ultima \\
\hline
\end{tabular}


Contoh:

Variasi $[e]$ dan $[a]$ / penultima

Variasi bunyi $[e] \sim[a]$ muncul dalam beberapa makna pada posisi penultima. Variasi tersebut terlihat dalam IPp, IP, dan IM. Secara teratur, bunyi $[e]$ ditemukan di IPp, sementara bunyi [a] ditemukan dalam IP dan IM. Deskripsi tersebut dapat dilihat dalam tabel berikut.

Tabel 5.

Variasi $[e] \sim[a]$ pada Posisi Penultima

\begin{tabular}{|l|l|c|c|c|}
\hline No & \multicolumn{1}{|c|}{ Makna } & IPp & IP & IM \\
\hline 100 & dagu & {$[$ dego? $]$} & {$[$ dageo? $]$} & {$[$ dagu? $]$} \\
\hline 107 & dada & {$[$ dedo $]$} & {$[$ dadeo $]$} & {$[$ dado] } \\
\hline 118 & jari & {$[$ jehəy $]$} & {$[$ jahiy $]$} & {$[$ jahiy $]$} \\
\hline 234 & wanita yang bercerai & {$[$ jendo $]$} & {$[$ jandeo $]$} & {$[$ jando] } \\
\hline 309 & sapi & {$[$ jewey $]$} & {$[$ jawiy $]$} & {$[$ jawiy $]$} \\
\hline 703 & bekerja & {$[$ gewe $]$} & {$[$ gawe $]$} & {$[$ gawe $]$} \\
\hline 705 & jatuh (orang) & {$[$ jetoh $]$} & {$[$ jateuh $]$} & {$[$ jateuh $]$} \\
\hline
\end{tabular}

\section{Inovasi Fonologis}

Inovasi fonologis dalam penelitian ini mengacu pada dua jenis, yaitu inovasi internal dan inovasi eksternal. Inovasi internal yaitu proses perubahan bahasa yang terjadi di dalam bahasa atau dialek itu sendiri, sedangkan inovasi eksternal merupakan proses perubahan bahasa atau dialek yang terjadi karena adanya pengaruh dari bahasa atau dialek lain. Inovasi sebagai suatu perubahan bahasa terjadi setelah menempuh proses perjalanan yang cukup panjang dan sepanjang perjalanannya tersebut mengalami berbagai bentuk retensi dan inovasi.

Inovasi bahasa (isolek) yang dikaji dalam penelitian ini terbatas pada proses perubahan wujud Isolek Kerinci di Kecamatan Bukitkerman dalam bidang fonologi dari bentuknya semula yang dikenali sebagai protobahasan PIBK sampai menjadi IBK sekarang ini. Berikut dijelaskan analisis data inovasi bahasa.

PIBK *s / ultima $\left(<\mathrm{PM}^{*} \mathrm{~s}\right)>\operatorname{IM} f, z$.

PIBK *s pada posisi ultima (yang berasal dari

$\mathrm{PM}^{*}$ s) berubah menjadi $f$ dan $z$ dalam IM.

Contoh;

PIBK *susaw'susu' (<PM *susu(A)) > IMsufow.
PIBK *pusa" 'pusat' (< PM *pusat) > IMpufat. PIBK *nasay'nasi' (< PM *nasi(A)) >IMnafay. PIBK *pisaK 'pisang' (<PM * pisah) $>$ IMpifaK. PIBK *nsau'anak termuda' >IM nzu.

PIBK *h / -\#- $\left(<\right.$ PM $^{*}$ r) $>$ IPp dan IP Ø. PIBK *h pada posisi awal dan posisi akhir (yang berasal dari PM *h) berubah menjadi $\varnothing$ dalam IP dan IPp.

Contoh;

PIBK *inih'ini' >IPnai.

PIBK *ituh'itu' $(<\mathrm{PM} *(\mathrm{i}) \mathrm{tu}(\mathrm{P}))>$ IPtaw. PIBK *hatay'hati' (< PM *hati) > IPp ati.

Temuan pada daerah pengamatan yang diinventarisasi adalah 41 data; PIBK *a / \#- (< PM *a) > IM Ø; PIBK *a / antepenultima (< PM *a) > IPP, IP dan IM o; PIBK *a / -h\# (< PM *a) > IPp dan IP $o$; PIBK *a /-\#K (< PM *a, ${ }^{*}$ ) $>$ IPp ai, au; IP ea, ao, ae; IM ia, ou; PIBK *a / - P (<PM *a) > IP $e ;$ PIBK *a / penultima $(<$ PM *a) > IPp e; PIBK *a? / -\# (<PM *a?) > IPp $o$; PIBK *i / \#- $\left(<\mathrm{PM} *_{\mathrm{i}}\right)>$ IP dan IM $\varnothing ;$ PIBK $*_{\mathrm{i}} / \operatorname{ultima}\left(<\mathrm{PM} *_{\mathrm{i}}\right)>\mathrm{IM} e ; \mathrm{PIBK} *^{*} \mathrm{u} /$ \#- $(<$ PM *u) > IPp, IP, dan IM Ø; PIBK *u / -h $(<$ $\mathrm{PM} * \mathrm{u})>\mathrm{IP}$ o, IM oic; PIBK *ə / \#- $(<\mathrm{PM} * \partial)>$ IP dan IM Ø; PIBK *ə / -\# ( < PM *ə) > IPP dan 
IP ə, IM iy; PIBK *e / -\# ( < PM *e) > IPp, IP dan IM ea; PIBK *o / -\# ( < PM *a) > IP eo, IM ou; PIBK *o / -\# (< PM *a) > IPp o, IP dan IM $o, a o ; \mathrm{PIBK} * \mathrm{o} /-\mathrm{K} \#(<\mathrm{PM} * \mathrm{a})>\mathrm{IPp} o a ; \mathrm{IP} a o$, eu, eo; IM ou, ao, eo, eu, oic; PIBK *o? / -\# (< PM *u?) > IPp u?; PIBK *aw / -\# / ( < PM *aw) > IM ow; PIBK *ew / -\# (< PM *uw) > IP iw, IM uw; PIBK *iy / -\# ( < PM *iy) > IPp əy; PIBK *p / \#- (< PM *p) > IPp dan IM Ø; PIBK ${ }^{*} \mathrm{p} /$-\# $\left(<\mathrm{PM}{ }^{*} \mathrm{p}\right)>$ IPp, IP, dan IM P; PIBK *b / \#- $\left(<\mathrm{PM}{ }^{*} \mathrm{~b}\right)>$ IP dan IM $\varnothing ;$ PIBK *t / -\# $(<$ PM *t) $>$ IP P; PIBK *k / \#- $(<$ PM *k) $>$ semua isolek $\varnothing$; PIBK *k / \#- $\left(<\mathrm{PM}^{*} \mathrm{~g}\right)>\mathrm{IPp} g$; PIBK ${ }^{*} \mathrm{~g} /$ \#- $\left(<\mathrm{PM}{ }^{*} \mathrm{~g}\right)>$ IP dan IM $\varnothing ;$ PIBK *m / \#- $\left(<\mathrm{PM}{ }^{*} \mathrm{~m}\right)>\mathrm{IP} \varnothing ;$ PIBK *n / -\# $\left(<\mathrm{PM}{ }^{*} \mathrm{n}\right)>$

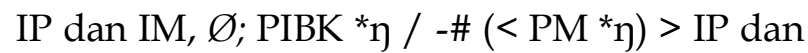
$\mathrm{IM} \eta ; \mathrm{PIBK}^{*} \eta /$-\#- $\left(<\mathrm{PM}{ }^{*} \mathrm{\eta}\right)>\mathrm{IPp}, \mathrm{IP}$, dan

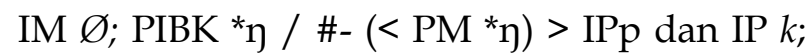
PIBK *s / ultima $\left(<\mathrm{PM}{ }^{*} \mathrm{~s}\right)>\mathrm{IM} \int, z$; PIBK *d / \#- $(<\mathrm{PM} * \mathrm{~d})>$ IP dan IM $\varnothing$; PIBK *h / -\#- $(<$ $\left.\mathrm{PM}^{*} \mathrm{r}\right)>\mathrm{IPp}$ dan IP $\varnothing$; PIBK *h $(\mathrm{h} \sim \varnothing) / \mathrm{V}-\mathrm{V}$ $\left(<\mathrm{PM}{ }^{*} \mathrm{r}\right)$ IPp dan IP $\varnothing ;$ PIBK *n / \#- $\left(<\mathrm{PM}{ }^{*} \mathrm{n}\right)$ $>$ IPp c; PIBK *? / -\# (<PM *?) > IM t; PIBK *1 / -\#- $\left(<\mathrm{PM}{ }^{*} \mathrm{l}\right)>\mathrm{IPp}$ dan IM $\varnothing ;$ PIBK * ${ }^{*}$ / \#$\left(<\mathrm{PM}{ }^{*} \mathrm{~W}\right)>$ IP dan IM $\varnothing$.

Hasil analisis 41 data inovasi fonologis tersebut bahwa IM memunculkan hasil inovasi fonem vokal dan konsonan sebesar 25; IP sebesar 24; dan IPp sebesar 20 dengan jumlah keseluruhan bentuk inovasi yang dijadikan percontoh sebesar 69. Selanjutnya hasil tersebut dilakukan penghitungan guna mengetahui isolek titik pengamatan mana yang mengalami proses perubahan atau inovasi yang paling besar (isolek yang inovatif) berdasarkan persentase.

Isolek yang mempunyai bentuk inovasi terbesar dalam tataran fonologis yang mencakup inovasi fonem vokal dan konsonan adalah IM dan IP masing-masing berjumlah $36.23 \%$ dan $34.78 \%$, sementara IPp menunjukkan proses inovasi yang lebih sedikit dibandingkan dengan IP dan IM sebesar $28.99 \%$. Oleh karena itu, IM dan IP merupakan isolek yang inovatif sedangkan IPp adalah isolek yang konservatif. Dengan demikian IM dinyatakan sebagai isolek yang inovatif.

Berdasarkan hasil rekonstruksi fonologis telah dilakukan di atas, ditemukan beberapa kaidah perubahan bunyi yang dikemukakan oleh Crowley (1992:39-57). Kaidah perubahan bunyi didapatkan seperti: Metatesis dalam PIBK */a/ pada bunyi /ia/ dan /ai/.Aphaeresis terjadi dalam */a/,*/i/,*/u/, $* / a /, * / p /, * / b /, * / k /, * / g /, * / m /, * / n /$, $* / \eta /, * / d /, * / h /, * / l /$, dan */w/. Vowels Breaking (pemecahan vocal) terjadi dalam * $/ a$ / dengan pemecahan bunyi $/ a /$ menjadi ai dan ia. Fonem */o/ memunculkaneo, oa, ao, eo, eu, eo, ou, oic dan ou. Fonem */e/ pecah menjadi ea. Apokope nampak dalam */m/,*/n/,*/ $/$, $* / h /$, dan */l/. Sinkope yaitu menghilangnya bunyi di tengah kata yang terdapat pada fonem */h/.

\section{Retensi Fonologis}

Bentuk-bentuk pemertahanan fonem dari daerah pengamatan didapatkan 25 data fonem, yakni: PIBK *a / \# penultima (< PM ${ }^{*}$ a) > semua isolek $a$; PIBK *i / penultima (< PM *i) > semua isolek I; PIBK * $\mathrm{u} /$ penultima ( $\left.<P M{ }^{*} u\right)>$ semua isolek $u$; PIBK *o / ultima, antepenultima ( $<\mathrm{PM}{ }^{*}$ ə) $>$ semua isolek $\partial$; PIBK *e / ultima $\left(<\mathrm{PM}{ }^{*} \mathrm{e}\right)>$ semua isolek $e$; PIBK *o / -\# ( < PM*a) > semua isolek $o$; PIBK ${ }^{*} \mathrm{p} /$ \#-, ultima $\left(<\mathrm{PM}{ }^{*} \mathrm{p}\right)>$ semua isolek $p$; PIBK *b / \#-, ultima $(<\mathrm{PM} * \mathrm{~b})>$ semua isolek $b$; PIBK *t / \#-, ultima $(<\mathrm{PM} * \mathrm{t})>$ semua isolek $t$; PIBK ${ }^{*} \mathrm{k} /$ \#-, penultima, ultima ( < $\left.\mathrm{PM}{ }^{*} \mathrm{k}\right)>$ semua isolek $k$; PIBK * $\mathrm{g} /$ \#-, ultima ( $<$ PM * ${ }^{*}$ ) > semua isolek $g$; PIBK *m / \#-, ultima $\left(<\mathrm{PM}^{*} \mathrm{~m}\right)>\mathrm{IPp}$, IP, dan IM $m ;$ PIBK *n / -\#, ultima $\left(<\mathrm{PM}^{*} \mathrm{n}\right)>$ semua isolek $n$; PIBK ${ }^{*} \eta /$-\# $\left(<P M{ }^{*} \eta\right)$ semua isolek $\eta$; PIBK *s / \#$\left(<\mathrm{PM}{ }^{*} \mathrm{~s}\right)>$ semua isolek s; PIBK *d / \#-, ultima $(<\mathrm{PM} * \mathrm{~d})>$ semua isolek $d$; PIBK *h / \#-, ultima $\left(<\mathrm{PM}{ }^{*} \mathrm{~h}\right)>$ semua isolek $h$; PIBK *n / \#-, ultima $\left(<\mathrm{PM}^{*} \mathrm{n}\right)>$ semua isolek $n$; PIBK ${ }^{*}$ l / \#-, ultima $\left(<\mathrm{PM}{ }^{*}\right.$ l) $>$ semua isolek $l$; PIBK ${ }^{*} \mathrm{~W} /$ ultima $\left(<\mathrm{PM}{ }^{*} \mathrm{~W}\right)>\mathrm{IPp}, \mathrm{IP}$, dan IM $w$; PIBK *y / ultima $\left(<P M{ }^{*} y\right)>$ semua isolek $y$; 
PIBK *r / \#-, ultima dan penultima $\left(<P M{ }^{*} r\right)$ $>$ IP, IPP, IM r; PIBK *j / \#-, ultima $(<\mathrm{PM} * \mathrm{j})>$ semua isolek $j$; PIBK ${ }^{*} \mathrm{C} / \#$-, ultima $\left(<\mathrm{PM}{ }^{*} \mathrm{C}\right)$ $>$ semua isolek $c$.

Contoh analisis

PIBK *1

PIBK *1 / \#-, ultima $\left(<\mathrm{PM}{ }^{*} \mathrm{l}\right)>$ semua isolek 1 .

Protofonem konsonan lateral alviolar PIBK * / l/ pada posisi awal dan ultima (yang berasal dari PM *l) menurunkan bentuk retensi pada semua isolek.

Contoh;

*1 / \#-

PIBK *lamo 'lama' (< PM *lama(? )) > IPp dan IM lamo, IP lameo.

PIBK *lintah 'lintah' (< PM *lintah) > semua isolek lintah.

*l / ultima

PIBK *salaK 'salang' > semua isolek salaK. PIBK *buluh 'buluh' > IPPbuloh, IP buleuh, IM buluh.

Berdasarkan hasil analisis retensi terdapat beberapa fonem vokal, diftong, dan fonem konsonan yang masih bertahan pada posisi tertentu di titik-titik pengamatan penelitian yang mencakupi IPp, IP, dan IM.

Jumlah keseluruhan bentuk retensi dari masing-masing titik pengamatan adalah IPp sebesar 44; IP sebesar 41; sementara IM sebesar 38 dengan jumlah keseluruhan bentuk retensi percontoh sebesar 123 .

Titik pengamatan tersebut masing-masing sebesar 35.78 \% (IPp) dan 33.33 \% (IP), sedangkan IM memperlihatkan proses retensi atau pemertahanan unsur lama yang lebih sedikit dibandingkan dengan IPp dan IP sebesar 30.89 $\%$.Oleh sebab itu, IPp dinyatakan sebagai titik pengamatan yang konservatif.

Perubahan secara fonologis sama halnya dengan adanya variasi-variasi yang disebabkan oleh faktor ekstralinguistik (luar bahasa). Faktor-faktor tersebut adalah faktor geografis, faktor budaya, dan faktor sosial.

\section{Faktor Geografis}

Faktor geografi merupakan hal yang memainkan peranan penting dalam proses variasivariasi isolek. Hal tersebut dapat diartikan bahwa jika daerah penelitian atau titik-titik pengamatan berada pada jarak yang berdekatan maka sedikit pula perbedaan yang didapatkan begitu pula sebaliknya. Pada penelitian ini berdasarkan hasil sinkronis yang berupa variasi antartitik pengamatan IPp dan IP menunjukkan persentase $0 \%$ atau tidak ada perbedaan disebabkan daerah IPp dan IP berdekatan dan sering melakukan kontak tutur. Namun antara IPp dan IM maupun IM dan IP menunjukkan persentase $0,25 \%$ atau juga tidak ada perbedaan.

Perbedaan kecil tersebut disebabkan geografi daerah IM jauh dari IPp dan IM sehingga ada beberapa bunyi atau fonem yang diserap dari daerah terdekat dengan IM (ITb) seperti $s$ menjadi $f$ dan $z$ pada posisi penultima, namun $s$ tetap dipakai apabila berada di awal kata.

\section{Faktor Budaya}

Faktor budaya juga merupakan hal yang menyebabkan terjadinya variasi-variasi dialek/ isolek. Perlu diketahui bahwa daerah Kabupaten Kerinci mempunyai kebudayaan berbeda-beda pada setiap desa-desa. Setiap budaya yang berbeda tentu saja memiliki variasi isolek yang berbeda pula. Oleh karenanya, keadaan kebahasan juga menimbumbulkan variasi pemakaian bahasa berdasarkan penuturnya. Contoh dalam kasus titik pengamatan dalam penelitian ini banyak dijumpai variasi leksikal dalam menyebutkan lema/entri kata. Kata yang bermakna 'satu' pada titik pengamatan didapatkan dua variasi leksikal dengan variannya; IPp sataw, IP cakae", dan IM cake. Kebudayaan yang beragamlah yang menimbulkan variasi-variasi leksikal pada masingmasing titik pengamatan tersebut.

\section{Faktor Sosial}

Dari segi sosial dialek merupakan identitas atau jati diri. Isolek-isolek yang digunakan oleh 
masyarakat Kerinci merupakan tanda jati diri masing-masing penuturnya. Setiap orang atau penutur pasti tahu dengan lawan tutur lainnya yang menggunakan dialek atau isolek daerah lain. Hal ini merupakan suatu bentuk kepedulian dalam memegang teguh, menyunjung tinggi serta rasa memiliki dialek/isolek yang dituturkannya. Faktor sosial yang memengaruhi variasi-variasi penutur bahasa dalam terjadinya inovasi kebahasaan adalah dipengaruhi oleh media elektronik seperti TV, Radio, media social, serta perubahan sosial oleh masyarakat penutur bahasa itu sendiri.

Dengan demikian, hasil dari keseluruhan penelitian ini merupakan penemuan baru dalam hal melihat variasi, merekonstruksi, inovasi, dan retensi pada isolek daerah yang diteliti yaitu isolek kerinci yang digunakan di Kecamatan Bukitkerman Kabupaten Kerinci Provinsi Jambi. Penelitian di daerah ini belum pernah dilakukan sebelumnya mengenai kajian dialektologi diakronis.

\section{PENUTUP}

Hasil analisis sinkronis ditemukan 25 variasi-variasi bunyi yang mencakup variasi vocal, konsonan, dan diftong serta 2 bunyi gugus konsonan. Berdasarkan hasil analisis diakronis ditemukan fonem PIBK dari hasil proses rekonstruksi protobahasa pada posisi tertentu. Fonem tersebut berupa enam fonem vokal dua gugus bunyi, tujuh diftong, dan sembilan belas fonem konsonan. Inovasi fonologis yang ditemukan berdasarkan kaidah perubahan bunyi, seperti: 1) metatesis; 2) afaresis; 3) pemecahan vokal; 4) apokop; dan 5) sinkop. Berdasarkan bukti-bukti sinkronis dan diakronis dengan menggunakan metode dialektometri serta hasil analisis data yang didapatkan di lapangan, IPp dinyatakan sebagai titik pengamatan yang masih mempertahankan isoleknya (konservatif).

Hasil-hasil analisis di atas dapat disimpulkan bahwa penelitian dialektologi diakronis yang dilakukan di Kecamatan Bukitkerman
Kabupaten Kerinci dengan menjadikan desa Pulaupandan (IPp), Pengasi (IP), dan Muak (IM) sebagai titik pengamatan menunjukkan bahwa adanya inovasi yang terjadi pada titik pengamatan tersebut.

Hal tersebut tidak hanya terjadi secara intralingual (inovasi internal), tetapi juga terjadi secara extralingual (inovasi external). Inovasi internal mencakup perubahan-perubahan bunyi yang ada dalam isolek tersebut sesuai dengan kaidah perubahan bunyi. Sementara itu, inovasi external terjadi adanya pengaruh faktor budaya, geografis, dan sosial.

\section{DAFTAR PUSTAKA}

Adelaar, K.A. 1992. Proto-Malayic: The Reconstruction of its Phonology and Parts of its Lexicon and Morphology. Canberra: A.N.U. Printing Service.

Ayatrohaedi. 1979. Dialektologi: Sebuah Pengantar. Jakarta: Pusat Pembinaan dan Pengembangan Bahasa Departemen Pendidikan dan Kebudayaan.

Crowley, Terry. 1992. An Introduction to Historical Linguistic. Melbourne Auckland: Oxford University Press.

Fox, Anthony. 1995. Linguistic Reconstruction: An Introduction to Theory and Method. New York: Oxford University Press.

Hock, H. H. 1988. Principle of Historical Linguistics. Amsterdam: dc Gruyter.

Kemp, J. A. 2006. Phonetic Transcription: History. Edinburgh UK: University of Edinburgh. Elservier Ltd. Alright Reserved.

Llamzon, Teodoro A. 1975. "Proto-Philippine Phonology". In: Archipel. Volume 9, pp. 2942. Persee: Ministere de I'Enseignement Superieur et de la Recherche.

Mahsun. 1995. Dialektologi Diakronis: Sebuah Pengantar. Yogyakarta: Gadjah Mada University Press.

Mahsun. 2005. Metode Penelitian Bahasa. Jakarta: Raja Grafindo Persada. 
Nadra dan Reniwati. 2009. Dialektologi; Teori dan Metode. Yogyakarta: Elmatera Publishing.

Nadra, Reniwati, dan Efri Yades. 2008. “Daerah Asal dan Arah Migrasi Orang Minangkabau di Provinsi Jambi Berdasarkan Kajian Variasi Dialektal". Makara, Sosial Humaniora, Vol 12, No. 1.

Nadra. 2006a. Rekonstruksi Bahasa Minangkabau. Padang: Andalas University Press.

Nadra. 2006b. Penuntun Penulisan Karya Ilmiah. Padang: Andalas University Press.

Sastra, Gusdi. 1994. "Protobahasa Minangkabau - Kerinci: Rekonstruksi Fonologi". Jakarta: Tesis S-2 Universitas Indonesia.

Sudaryanto. 1988. Metode Linguistik, Bagian Kedua: Metode dan Aneka Teknik Penggumpulan data. Yogyakarta: Gadjah Mada University Press.

Sudaryanto. 1993. Metode dan Aneka Teknik Analisis Bahasa.Yogyakarta: Duta Wacana University Press. 